\title{
Book Review: Assessing the Risk, Suicide Risk: The Formulation of Clinical Judgement
}

\author{
Michael Gray, MD \\ New York University Medical Center
}

Follow this and additional works at: https://jdc.jefferson.edu/jeffjpsychiatry

Part of the Psychiatry Commons

Let us know how access to this document benefits you

\section{Recommended Citation}

Gray, MD, Michael (1989) "Book Review: Assessing the Risk, Suicide Risk: The Formulation of Clinical Judgement," Jefferson Journal of Psychiatry. Vol. 7 : Iss. 1 , Article 12.

DOI: https://doi.org/10.29046/JJP.007.1.011

Available at: https://jdc.jefferson.edu/jeffjpsychiatry/vol7/iss1/12

This Article is brought to you for free and open access by the Jefferson Digital Commons. The Jefferson Digital Commons is a service of Thomas Jefferson University's Center for Teaching and Learning (CTL). The Commons is a showcase for Jefferson books and journals, peer-reviewed scholarly publications, unique historical collections from the University archives, and teaching tools. The Jefferson Digital Commons allows researchers and interested readers anywhere in the world to learn about and keep up to date with Jefferson scholarship. This article has been accepted for inclusion in Jefferson Journal of Psychiatry by an authorized administrator of the Jefferson Digital Commons. For more information, please contact: JeffersonDigitalCommons@jefferson.edu. 


\title{
Book Reviews
}

\section{Assessing the Risk}

\author{
SUICIDE RISK: THE FORMULATION \\ OF CLINICAL JUDGEMENT
}

John T. Maltsberger

New York University Press, New York, 1986

174 pp. $\$ 26.95$

Michael Gray, M.D.

Sidney Tarachow once wrote, "I remember one week I had three suicidal risks walking the streets of New York. I had a bad week end, but on Monday they all showed up very much alive." (1) Such words of insecurity from an experienced therapist are not the most encouraging for the beginning therapist; the evaluation of a patient for suicidality represents a particularly difficult and imposing responsibility. Probably many residents, myself included, can remember at least one time when he or she was called to evaluate a patient for suicidality, and all book learning related to suicide risk seemed to have left him or her. Such decisions sometimes need to be made in situations that often are not the most conducive for making thoughtful decisions, such as the pressured atmosphere of a busy, often under-staffed emergency room, or during the early hours of the morning. Compounding this difficulty is a more general one: we are often faced with such a multitude of different and new clinical situations that we often find ourselves without the proper fund of knowledge to make a wellinformed decision.

Dr. John Maltsberger's recent work entitled Suicide Risk: The Formulation of Clinical Judgement fills many of the needs of those looking for a highly informative, well-written book on the subject of evaluation for suicidality. It will be welcome reading for any resident who feels the need to sharpen his skills in objectively and accurately evaluating the potentially suicidal patient. The author of the book, a teacher at Harvard who has studied and written extensively on suicide, distills over 25 years of experience into a thoughtful, clear and highly readable presentation. The book's length of under 200 pages, and the clear style in which it is written, make it very accessible even when it seems as if one's schedule won't allow for anything more.

The main premise of this book is that each case should be evaluated through a process that organizes the case material around a psychodynamic 
formulation. The author, who is a practicing psychoanalyst, defines the psychodynamic formulation as the psychiatrist's attempt to organize and understand the patient's current distress as a result of an interplay of forces involving the patient's development, the nature of his current intrapsychic configuration, and his environment. The author asserts that the psychodynamic formulation is essential in order to objectively evaluate each patient.

The reader is taken through different aspects of the psychodynamic formulation, and his attention is always focused on the clinical relevance of the material. Early developmental problems which may predispose an individual in later life to psychopathology and suicidality are discussed, with special emphasis on clinical examples to support many of the points.

The author also emphasizes the uniqueness of each case, and the fact that the psychiatrist must evaluate each individual's response to a life stressor through an appreciation of the psychopathology of that individual. Special emphasis is placed on the vulnerability to suicide of those individuals who have suffered early trauma, and whose intrapsychic development has undergone a distortion or arrest. An over-reliance on external supports to modulate one's self-esteem and regulate one's inner drives is discussed at length as particularly predisposing to suicide, especially when such supports are threatened or lost in adult life.

Much important clinical information is contained within the narrative of the book; well-known correlates of suicide-epidemiologic, demographic, and diagnostic facts-are presented within the context of making a psychodynamic formulation. For example, depression, alcoholism, and recent loss are not simply discussed as correlates that, when presenting together in the same individual, predict a high risk of suicide. Rather, the depressed alcoholic who suffers a recent loss is discussed in the context of how a recent loss may be experienced by his psyche, as well as inferences that the clinician can make regarding early trauma leading to his current psychopathology. Similar discussions, which relate epidemiologic or demographic data to the context of clinical presentation and understanding, occur throughout the book. Such discussions lend a clarity and vitality to the material. Appendices to the book, outlining the mental status exam and a weighted questionnaire to evaluate for suicidality, add to the clinical importance of this book.

I think that the book fills an important gap in the psychiatric literature, and any resident who reads this book with understanding will benefit from the author's experience and thoughtfulness and will be able to evaluate for suicidality with greater clinical acumen. This book belongs on every resident's bookshelf.

\section{REFERENCE}

1. Tarachow S: An Introduction to Psychotherapy, New York, International University Press, p. 268, 1963 